\title{
Aprender na clausura: a aula pública do recolhimento da Caridade de Braga, no século XVIII
}

\author{
Learning in the cloister: 'the public class' of the shelter of the Caridade \\ of Braga, in the 18th century
}

\section{Maria Marta Lobo de Araújo ${ }^{1}$}

\section{RESUMO}

Neste trabalho analisamos a aprendizagem feita pelas mulheres nos recolhimentos, dando particular atenção ao da Caridade de Braga, onde em finais do século XVIII se criou uma "aula pública". Espaços de reclusão, estas casas constituíam-se como locais de preservação da honra feminina, mas também centros de aprendizagem de competências associadas à vida doméstica. Embora em todos os recolhimentos se praticasse a leitura e a escrita, em muito poucos se ensinavam essas práticas. No da Caridade foi criada uma escola para meninas, com a particularidade de ser um espaço de clausura que diariamente se abria para receber alunas externas, embora tivesse também alunas internas.

Palavras-chave: recolhimento, Caridade, mulheres, "aula pública"

\section{ABSTRACT}

In this work we analyze the learning done by the women in the shelters, paying special attention to the Recolhimento of Braga, where in the late 18th century a "public class" was created. Sections of seclusion, these houses constituted like places of preservation of the feminine honor, but also centers of learning of competences associated to the domestic life. Although reading and writing were practiced in all the retreats, very few were taught these practices. In the Caridade, a school was created for girls, with the peculiarity of being a cloistered space that opened daily to receive external students, although it also had internal students.

Keyword: shelter, charity, women, "public class". 


\section{Introdução}

Desde sempre que nos conventos femininos e recolhimentos se leu e escreveu, embora o domínio dessas técnicas nem sempre se alargasse a todas as mulheres que viviam nessas instituições.

A historiografia mais recente sobre a cultura escrita feminina tem demonstrado a grande iliteracia das mulheres na Idade Moderna, mas também os progressos feitos em alguns contextos e em certos grupos sociais. Prova ainda que se há países e regiões onde este tema tem sido recentemente muito trabalhado, noutros os poucos estudos existentes é a tónica dominante.

Em termos europeus não há dúvida de que a história cultural e a história das mulheres conheceram nas últimas duas décadas um momento excecional. Livros, artigos, congressos, seminários, conferências e projetos de investigação atestam essa mesma realidade. A produção historiográfica é muito significativa em alguns países, como acontece, por exemplo, na vizinha Espanha, onde são conhecidos vários trabalhos sobre o estado da arte ${ }^{2}$. Estes e outros textos têm possibilitado um debate sobre a temática, facto que se louva, também, por, uma vez mais, chamar a atenção sobre a temática.

Em Portugal, os estudos sobre as mulheres conhecem tendências semelhantes, mas a realidade é diferente. Sem se esquecer o enorme contributo de alguns autores e trabalhos ${ }^{3}$, é ainda extenso o caminho a percorrer, basta recordar a inexistência de uma História das Mulheres.

Pese embora existir um melhor conhecimento atual sobre a história da mulher na Idade Moderna, a análise cultural e, no caso concreto, a cultura escrita feminina, é talvez o aspeto menos trabalhado e mais desconhecido, quer em Portugal, quer no estrangeiro. As

\footnotetext{
${ }^{2}$ Veja-se, entre muitos outros, os trabalhos de CAPEL, R. M.. La mujer española en el siglo XVIII: estado de la cuestión. IN: Coloquio Internacional "Carlos III y su siglo". Madrid: II, p. 511-517; BOLUFER, M.. Historia de las mujeres en la época moderna: selección de la bibliografia reciente. Cuadernos de Historia Moderna, p. 127-224,1997; GARCIA, Serrana. Una mirada a la evolución historiográfica de la historia de las mujeres. Semata. Ciencias sociais e humanidades, 20, p. 155-188, 2008; REY CASTELAO, Ofelia. La historia de las mujeres en Galicia. Un estado se la cuestión (1988-2008). Minius, 17, p. 191-234; 2009; LOPÉZ-CORDÓN, María Vitória. Los estúdios históricos sobre las mujeres en la Edad Moderna: estado de la cuestión. Revista de Historiografia, 22, p. 147-181, 2015.

${ }^{3}$ Consulte-se, entre outros, os trabalhos de SILVA, Francisco Ribeiro da. O ensino público em Portugal no século XVII. IN: Primeiro encontro de História da Educação em Portugal. Lisboa: Fundação Calouste Gulbenkian, 1988, p. 115-124; BRAGA, Isabel M. R. Mendes Drumond. Cultura, Religião e Quotidiano. Lisboa: Hugin, 2005; MORUJÃO, Isabel; SANTOS Zulmira. Literatura cultura popular em Portugal e no Brasil-homenagem a Arnaldo Saraiva. Porto: CITCEM, Afrontamento, 2011. MORUJÃO, Isabel. Una escritura feminina diferente: los manuscritos culinários conventuales portugueses de la Edad Moderna. IN: Letras en la Celda. Cultura escrita de los conventos femininos de la España Moderna. Madrid: Iberoamericana-Vervnert, 2014, p. 439-455; Por trás da grade. Poesia conventual feminina em Portugal. Lisboa: Imprensa Nacional Casa da Moeda, 2013; Bibliografia Monástica Feminina. Lisboa: Centro de Estudos de História Religiosa, 1995; Uma tipologia de quase silêncio. Um sermão de clarissa: texto e contexto. IN: Vozes da Vida Religiosa Feminina. Experiências, Textualidades e Silêncios (Séculos XV-XXI). Lisboa: Centro de Estudos de História Religiosa/ Universidade Católica Portuguesa, 2015; LOPES, Maria Antónia. Mulheres, espaço e sociabilidade. A transformação dos papéis femininos em Portugal à luz de fontes literárias (segunda metade do século XVIII). Lisboa: Livros Horizonte, 1989; MAGAHLÃES, Justino. Ler e escrever no mundo rural do Antigo Regime. Braga: Universidade do Minho, 1993.
} 
dificuldades colocadas passam, em muitos casos, pela falta de fontes diretas em que se possa analisar, por exemplo, a ligação da mulher ao mundo da cultura. Esta situação não é válida para todos os grupos sociais, mas estende-se no período em análise para a esmagadora maioria das mulheres. Todavia, deve sublinhar-se que mesmo entre as alfabetizadas existiam vários níveis de conhecimento e de domínio das técnicas de ler e de escrever.

A questão da alfabetização feminina é uma temática pouco analisada, mas sem ela não se poderá equacionar a ligação das mulheres ao mundo dos livros, à produção de textos e à leitura. Há, todavia, que sinalizar um campo de análise onde o estudo da cultura feminina tem colhido maior proveito. Os estudos respeitantes ao mundo em clausura e da assistência têm dado a conhecer as vivências femininas e a sua articulação com a leitura e a escrita, embora, como refere Ana Xisto, os contextos geográficos desempenharam neste particular uma grande importância. Como refere, instituições como colégios, conventos, recolhimentos e outros estão situados principalmente nas cidades e nas vilas, enquanto o campo carece dessas instituições ${ }^{4}$. No mundo rural, a realidade era bem outra, como já é conhecido para a vizinha região da Galiza 5 .

Apesar de serem poucas as que dominavam as técnicas da leitura e da escrita até ao século XVIII, quando o ensino feminino se largou um pouco mais, sempre houve mulheres que leram e escreveram. Pertenciam aos estratos superiores ou aprenderam em instituições de assistência ou religiosas, mas muitas foram educadas em sua própria casa. Escreviam cartas ${ }^{6}$ e bilhetes a pessoas amigas e a familiares, dando notícias ou perguntado por elas, mantendo um espaço de intimidade que lhes proporcionava alguma autonomia. Porém, se a maioria das mulheres não dominava a técnica da escrita, esse facto reflete-se na produção, não se estranha existirem menos textos produzidos por mulheres que por homens.

A propósito das que sabiam escrever, interessa perguntar: Que textos produziam? Com que objetivo o faziam? A quem se dirigiam? Estas e outras perguntas esclareceriam sobre as produtoras dos textos, o objetivo da escrita e os assuntos versados nela.

A escrita e a leitura proporcionavam momentos de intimidade, de encontro consigo mesmas, eram ocasiões de evasão, de refúgio do público e do domínio do privado.

Nos conventos e recolhimentos, as mulheres tinham a obrigação de registar em livros próprios várias matérias e de fazer leituras individuais e em comunidade. As regentes ou superioras eram sempre detentoras dessas competências, bem como as escrivãs, mas nos

\footnotetext{
${ }^{4}$ Leia-se a importante síntese elaborada por SIXTO BARCIA, Ana Maria. Mujeres y cultura letrada en la Galicia Moderna. Santiago de Compostela: Facultade de Xeografía e Historia, Universidade de Santiago de Compostela, 2015, p. 47-55. Tese de Doutoramento policopiada.

${ }^{5}$ Veja-se LÓPEZ, Roberto J.. De la cultura material a la cultura letrada. IN: DUBERT, Isidro (coord.). Historia de la Galicia Moderna. Santiago de Compostela: Universidade de Santiago de Compostela, 2012, p. 389-390.

${ }^{6}$ ALMEIDA, Teresa Sousa de. Correspondências. Usos da carta no século XVIII. IN: MONTEIRO, Nuno Gonçalo; ALMEIDA, Teresa Sousa de; ANASTÁCIO, Vanda (org.), Correspondências. Usos da carta no século XVIII. Lisboa: Edições Colibri/Fundação das Casas de Fronteira e Alorna, 2005.
} 
recolhimentos nem todas as mulheres sabiam ler e escrever. Mas se nestes espaços isso se verificava, havia também quem fora deles, no universo das consideradas letradas, dominasse alguns rudimentos da escrita, mas não soubesse ler. Esta realidade não era incomum e pode, por exemplo, estar associada à necessidade de efetuar alguns registos, mas não ser tão comum a dedicação à leitura.

Em muitos conventos, algumas religiosas escreveram livros sobre a história da instituição ou sobre vidas de santos, normalmente de santas ligadas à sua Ordem ou ao seu cenóbio, propagandeando as suas virtudes e elogiando a sua santidade ${ }^{7}$. Por essas obras passa muita da vida da instituição, dando voz aos quotidianos intramuros e criando memória de algumas das personalidades por eles guardados. Os espaços de clausura, conventuais ou não, exigiam tempos de leitura e possuíam mecanismos que a facilitavam: a existência de livros de espiritualidade e de vidas de santos, mas também outros mecanismos proporcionadores, como seja o silêncio, tempos de leitura, tempo e o recolhimento. Constituíam importantes meios de a facilitar e exercitar ${ }^{8}$. No coro sempre se faziam leituras, muitas delas em grupo. Porém, na cela e no coro era também possível fazer leituras individuais, permitindo à leitora o domínio individual do texto lido, sem ter de o partilhar com a comunidade em que estava inserida ${ }^{9}$. Esta leitura silenciosa denotava ainda alguma familiaridade com esta prática e proporcionava uma relação direta com o livro. A ligação entre o livro, o leitor e o espaço de intimidade vai ganhando força com o avanço do século XVII em alguns contextos europeus, como se verificou em França ${ }^{10}$ e na Inglaterra ${ }^{11}$, mas desenvolve-se e alarga-se na centúria seguinte.

No século XVIII, com o Iluminismo e a forma como alguns homens ilustres começam a ver as mulheres, o acesso destas à alfabetização altera-se, alcançando contornos distintos, sobretudo nas cidades.

Enquanto os espaços de clausura feminina se esforçam por dotar as mulheres de competências no campo da leitura e da escrita, promovendo a leitura religiosa, no mundo laico avança o ensino e a prática de ler e de escrever nas mulheres.

\footnotetext{
${ }^{7}$ Para o convento feminino de Nossa Senhora da Conceição, onde uma das suas religiosas escreveu no século XVIII um livro sobre a instituição, leia-se o trabalho de SILVA, Ricardo. Casar com Deus: vivências religiosas e espirituais femininas na Braga Moderna. Braga: Universidade do Minho, 2011, p. 421-466, tese de Doutoramento policopiada. Para outros conventos confira-se MORUJÃO, Isabel. Poesia e santidade: alguns contributos para uma percepção do conceito de santidade, a partir de duas biografias devotas de religiosas do século XVIII português. Via Spiritus, nº 3, p. 235-261, 1996.

${ }^{8}$ LÓPEZ-CORDÓN, María Vitória. La fortuna de escribir. Escritoras de los siglos XVII e XVIII. IN: MORANT, Isabel (dir.). ORTEGA., M.; LAVRIN, A.; PERÉZ CANTÓ, P. (orgs.). Historia de las mujeres en España y América Latina. II, Madrid: Cátedra, 2005, p. 199-200.

${ }^{9}$ CHARTIER, Roger, As práticas da escrita. IN: ARIÈS, Philippe; DUBY, Georges (dir.). História da vida privada. Do Renascimento ao Século das Luzes. Porto: Ed. Afrontamento, 1990, p. 126.

${ }^{10}$ CHARTIER, Roger; JULIA, Dominique; CAMPĖRE Marie Madeleine. L'éducation en France du XVIe ao XVIIIe siècles. Paris: SEDES, 1976.

${ }^{11}$ CHARTIER, Roger. As práticas da escrita. In: ARIÈS, Philippe; DUBY, Georges (dir.). História da vida privada ..., p. 141.
} 
Educar integrou as preocupações iluministas, por se entender que através da educação se atingiria o progresso e com ele a felicidade dos povos. Em vários contextos europeus considerava-se que a falta de educação era causadora de atraso, impondo-se o inverso da situação, e a inclusão das mulheres nessa mudança. A educação devia, pois ter uma importância social, que reverteria a favor do bem público.

Na Europa como em Portugal foram muitos os que defenderam mudanças no campo da educação feminina. Na análise produzida pelos homens das Luzes está em observação o papel social da mulher, a sua posição enquanto esposa e mãe e em alguns deles a valorização cultural feminina. Recorde-se para Portugal a posição de Luís António Verney e a defesa por si feita acerca do acesso da mulher à cultura ${ }^{12}$.

As capacidades das mulheres eram reconhecidas e entendia-se que a educação se tornava necessária ao progresso, dando realce às mulheres, não apenas enquanto educadoras dos seus filhos, mas igualmente como esposas. No fundo, tratava-se também da sua valorização pessoal. Continuamos a referir-nos apenas a algumas mulheres, ou seja, às que pertenciam aos estratos sociais mais elevados. Porém, como menciona Isabel Drumond Braga as opiniões oscilavam entre os que mantinham uma postura mais conservadora e os que defendiam as "capacidades intelectuais femininas e a necessidade de educação para as mulheres", embora continuassem a advogar a sua alocação à família e, por conseguinte, a sua incapacidade de sobreviverem de forma autónoma e independente ${ }^{13}$. A educação das mulheres era defendida na medida em que ela se devia tornar mais culta para ser mais útil à família, nomeadamente enquanto educadora, dando bons ensinamentos e exemplos. $O$ mesmo se aplicava para a sua função de esposa.

Entendimento semelhante ao de Verney apresentava Ribeiro Sanches, quando defendeu a necessidade de aprendizagem das mulheres em termos culturais. $O$ seu programa cultural para as mulheres era mais diversificado que o do autor do Verdeiro Método de Estudar, mas as finalidades eram idênticas: as mulheres deviam cultivar-se para melhor acompanharem e entenderem os seus maridos e, simultaneamente, serem melhores educadoras dos seus filhos ${ }^{14}$. A cultura escrita das mulheres não era entendida como uma ferramenta importante que as valorizaria em termos pessoais e sociais, mas serviria apenas para as melhorar no seu papel de esposas e mães. Apesar de possuírem mais instrução, as mulheres continuavam maioritariamente circunscritas à casa, embora não desconheçamos as que tiveram um papel muito relevante da sociedade do seu tempo.

\section{Ler e aprender a ler nos recolhimentos}

\footnotetext{
${ }^{12}$ VERNEY, Luis António. Verdadeiro Método de Estudar. vol. 5, Lisboa: Sá da Costa, 1953, p. 123-145.

${ }^{13}$ BRAGA, Isabel M. R. Mendes Drumond. Cultura, Religião..., p. 137.

${ }^{14}$ BRAGA, Isabel M. R. Mendes Drumond. Cultura, Religião..., p. 147-148.
} 
Aprender na clausura convoca-nos para duas situações que se entrelaçam entre si. A de viver em contexto fechado e aí adquirir um conjunto de competências, normalmente atribuídas ao sexo feminino: costura, bordados e outros trabalhos de mãos, aos quais se juntavam também os conhecimentos culinários; e a aprendizagem da leitura e da escrita nesse mesmo espaço.

Neste trabalho estudamos o recolhimento da Caridade de Braga enquanto instituição de ensino, dando a conhecer o funcionamento da sua "aula pública" no século XVIII.

Destinados a mulheres, os recolhimentos assumiram na Idade Moderna um papel fundamental na guarda e preservação da honra feminina, através da clausura, da oração e do trabalho ${ }^{15}$. Podiam dedicar-se a mulheres honradas, normalmente sob o patronato de Nossa Senhora ou a mulheres arrependidas, que tinham manchado a sua honra e queriam agora mudar de vida. Estes últimos invocavam geralmente Santa Maria Madalena, a pecadora, como patrona.

Estas instituições ganharam força no pós-Trento, funcionavam em contexto urbano, normalmente nas cidades, mas existiram também em algumas vilas. Pautavam-se por princípios, em vários aspetos, muito semelhantes aos dos conventos e mosteiros. Todas as que ingressavam nestas casas estavam sujeitas às mesmas normas e ao rigor da vida em clausura. Os recolhimentos distinguiam-se dos conventos, pois as que os procuravam não tinham como objetivo a vida religiosa. Por isso, nestas casas as mulheres não tomavam ordens sacras, nem tinham um ano de noviciado e eram nelas integradas apenas para residirem algum tempo. Eram, por isso, lugares temporários, onde se guardavam as mulheres e se dotavam de algumas competências, consideradas essenciais à sua condição feminina ${ }^{16}$. Porém, na prática, muitas passavam largos anos nos recolhimentos, acabando várias por encontrar neles a sua última morada ${ }^{17}$. Serviam de resguardo durante um período em que as mulheres eram consideras em risco, pela juventude, orfandade e desamparo e, por isso, estarem mais vulneráveis ao descaminho, pelo isolamento ou ausência temporária dos maridos, ou ainda para se converterem depois da honra perdida ${ }^{18}$. Como se constata, as mulheres eram encaminhadas para estas instituições para serem retiradas do mundo, numa altura em que se podiam perder ou, já perdidas moralmente, precisarem de mudar de vida e converter-se.

\footnotetext{
${ }^{15}$ Leia-se GANDELMAN, Luciana Mendes. Mulheres para um império: órfãs e caridade nos recolhimentos femininos da Santa Casa da Misericórdia (Salvador, Rio de Janeiro e Porto-século XVIII). Campinas: UNICAMP, 2005, p. 220-235, tese de Doutoramento policopiada.

${ }^{16}$ LOPES, Maria Antónia. Protecção Social em Portugal. Coimbra: Imprensa da Universidade, 2010, p. 97-102.

${ }^{17}$ CASTRO, Maria de Fátima. O Recolhimento das Beatas de Santo António do Campo da Vinha. Bracara Augusta, vol. XLVI, p. 169-249, 1995-1996.

${ }^{18}$ BELO, Maria Filomena Valente. Os recolhimentos femininos e a expansão (séculos XVI-XVII). IN: O rosto feminino da expansão portuguesa. Actas do congresso internacional. Lisboa: Comissão Nacional para a Comemoração dos Descobrimentos Portugueses, vol. I, 1994, p. 678; MONTESERRAT CARBONEL i Esteller. Sobreviuver a Barcelona. Dones, pobresa i assistência al segle XVIII. Barcelona: Euno Editorial, 1997, p. 127.
} 
Tratava-se de uma reclusão que tinha como grande objetivo viver uma vida para a oração, afastando-as do isolamento em que muitas se encontravam.

Para se ingressar num recolhimento era preciso pagar, logo nem todas as famílias o podiam fazer, todavia, em alguns dos de Braga, os arcebispos asseguravam a permanência, pagando para as mais pobres entrarem e se manterem. No de Santo António, administrado pela Misericórdia a partir de 1608, era esta confraria que suportava todos os gastos das mulheres com o legado que o instituidor deixou ${ }^{19}$. No caso do de Santa Maria Madalena, as 12 convertidas eram também suportadas pela Mitra, bem como a regente e a porteira. Mas na segunda metade de setecentos, havia quem estivesse a ser auxiliada pelo arcebispo, apenas por ser pobre. Ou seja, eram instituições que prestavam assistência a quem precisava.

O número de mulheres guardadas nestas casas era muito limitado. Quase todas trabalhavam com numerus clausus, o que significava que apenas algumas tinham acesso ao internamento. Porém, na prática com o decorrer do século XVIII e perante a grande procura de que foram alvo, estas casas romperam com o número limite e abriram as suas portas a um volume muito maior de mulheres, quase sempre através das porcionistas.

A vida nos recolhimentos era pautada pelo cumprimento de normas muito rígidas, onde se guardavam mulheres, retirando-as do mundo. Tratava-se de conservar ou reformar a honra das mulheres, o melhor bem considerado pela sociedade que estas possuíam.

Para além das mulheres do "numerus clausus", os recolhimentos acolhiam porcionistas e alguns deles educandas. Muitas das porcionistas e educandas ingressavam nestas instituições para se prepararem para o casamento. Estas mulheres pagavam o seu internato.

Estudar as condições em que se lia e escrevia nos espaços de clausura é ter em atenção desde logo o público envolvido e as instituições em causa. Se falarmos de conventos, sabemos também que nem todos eram iguais, ou seja, existiam alguns mais elitistas que outros, tendo como mecanismo seletivo o dote de pagamento. Essa realidade condicionava o universo de mulheres que guardavam, mas de uma forma geral as que iam parar a estas instituições, no caso das religiosas professas dominariam pelo menos os rudimentos da leitura e da escrita. Já o mesmo podia não acontecer nos recolhimentos, principalmente nos dedicados a recolher mulheres pecadoras. Mas nos restantes podia acontecer também que nem todas soubessem ler e escrever, embora saibamos que em muitos deles, algumas mulheres recebiam cartas e bilhetes e que também os escreviam. Estes meios de comunicação só saíam da instituição após escrutínios da regente e os recebidos passavam pelo mesmo crivo antes de chegarem à sua destinatária.

\footnotetext{
${ }^{19}$ MACHADO, Carla Manuela Sousa. Entre a clausura e o século: o recolhimento de Santo António do Campo da Vinha sob a administração da Misericórdia de Braga (séculos XVII-XVIII). Braga: Universidade do Minho, 2014, dis. de Mestrado policopiada.
} 
Nestes espaços de reclusão, o universo das leitoras é plural, não se aconselhando generalizações, principalmente entre recolhimentos e conventos. Aceder à palavra escrita e produzir textos não era para todas as mulheres internadas nestas instituições e dependia também dos contextos em que elas estavam localizados.

A pequena biblioteca existente em muitos desses espaços de clausura destinava-se à formação moral das leitoras, mas o livro era igualmente um elemento de devoção importante, por onde se praticava a leitura, feita em termos pessoais ou comunitários ${ }^{20}$.

No recolhimento de Santa Maria Madalena de Braga (instituição que começou a funcionar em 1722) e destinado a converter pecadoras, as mulheres tinham horas para ler e para ouvir ler. Os estatutos determinavam alguns momentos de leitura no coro alto e no refeitório, devendo ler as que dominavam essa técnica e na ausência de quem soubesse ler seria a regente a fazê-lo ou então o capelão do recolhimento. Porém, apesar de tudo estar pensando, de maneira a que as mulheres não fossem impedidas de ler ou ouvir ler, a propósito da leitura de livros espirituais, determinava-se também que "quando alguma das Recolhidas saiba ler o pode ensinar as outras pelos tais livros, e quando Não saibão o Padre Capellão terá esse cuidado"21. Apesar de não possuir uma escola formal, esta passagem é bem demonstrativa da forma como as recolhidas deviam proceder relativamente às suas companheiras que não dominavam a leitura. Também o capelão estava vinculado à tarefa de ensinar as que não sabiam ler, ensinando-lhes essa técnica. A leitura de livros espirituais era fundamental para o programa de conversão a que estas mulheres se sujeitavam. Era, evidentemente, muito mais importante que a escrita.

Estas leituras deviam ocorrer de manhã, quando iam ao coro alto. Durante as refeições, uma delas em voz em "que oussão todas" fazia leitura sobre os referidos livros para toda a comunidade. Se não houvesse quem soubesse ler, ficariam em silêncio. À tarde, novamente no coro alto rezavam o terço a Nossa Senhora em voz alta, e "havendo algua que saiba ler o rezarão por um dos livros que pera isso haverá e não havendo quem saiba ler A Regente meditará os Misterios"22. As mulheres eram novamente chamadas a ler, agora para rezar, existindo livros próprios por onde o podiam fazer.

Nos dias santos, quando se juntavam todas na casa do trabalho, para, em comunidade e prostradas perante a regente, assumirem os seus defeitos, a superiora falava-lhes sobre o caminho a seguir para se emendarem, para posteriormente lhes ler durante meia hora partes de um livro espiritual ou de vidas de santos. À tarde tinham mais meia hora de leitura. Nessa ocasião, a regente lia partes dos estatutos, para que não pudessem argumentar com falta de

\footnotetext{
${ }^{20}$ ALGRANTI, Leila Mezan. Livros de devoção, atos de censura. Ensaios de História do livro e da leitura na américa Portuguesa (1750-1821). São Paulo: Editora Hucitec, 2004, p. 55.

${ }^{21}$ Arquivo Distrital de Braga (doravante ADB), Fundo do recolhimento de Santa Maria Madalena, Estatutos do recolhimento de Santa Maria Madalena de Braga, não paginado.

${ }^{22}$ ADB, Fundo do recolhimento de Santa Maria Madalena, Estatutos do recolhimento de Santa Maria Madalena de Braga, não paginado.
} 
conhecimento das regras. Neste recolhimento, existiam momentos especiais de leitura, feitos quer pelas recolhidas, quer pela regente. Consideradas muito importantes para a sua formação, estas leituras auxiliavam na sua formação moral, mas tinham também como objetivo dotar as mulheres de competências para elas próprias procederem às leituras. Sem constituir um dos principais fundamentos desta casa, aprender a ler era relevante por auxiliar na conversão moral das mulheres.

O recolhimento possuía uma pequena biblioteca, composta por livros espirituais e livros de vidas de santos, mas não sabemos onde estes se guardavam. Também ignoramos se existiam livros particulares, trazidos aquando do ingresso das recolhidas, que as mesmas pudessem ter nas suas limitadas celas.

A escrita era praticada em termos institucionais e em termos particulares. Inicialmente era a regente que escrevia tudo o que fosse preciso registar. A primeira regente dominava perfeitamente a escrita ${ }^{23}$, mas nem sempre demonstrou capacidade para organizar o texto no espaço que tinha disponível, optando por aproveitar ao limite o papel. Sabemos que este era caro e que atuar dessa forma significava também economizar nas despesas, mas em certos momentos tornou-se corrente, impedindo o leitor de aceder ao conteúdo de forma fácil. Esta maneira de atuar não ficou circunscrita apenas a esta regente. Outras seguiram-lhe os passos, assim como algumas escrivãs.

Posteriormente, a regente, quando o recolhimento começou a crescer, foi assessorada por uma escrivã, recolhida eleita entre as que dominavam melhor a escrita e possuíam alguns rudimentos de cálculo. Esta oficial era um elemento muito importante, porquanto mantinha o cartório da instituição em bom funcionamento, uma vez que os livros eram anualmente inspecionados pela Mitra e aliviava a regente da tarefa de criar memória escrita.

Se em todos os recolhimentos, a escrita de cartas e bilhetes era muito auditada, neste recolhimento, pelas suas características, era ainda mais. Mas isso não impediu que as recolhidas escrevessem e recebessem missivas escritas. Sabemos que pelo menos uma delas trocava amiudadamente cartas com um sacerdote, o que causava escândalo e foi denunciado numa devassa. E uma outra recebia cartas de um soldado, facto gerador de um conflito que envolveu a porteira, que não consentia a entrega da missiva à destinatária sem prévia fiscalização da regente. Não disposta a que os seus segredos fossem públicos, a interessada envolveu-se fisicamente com a porteira, subtraiu-lhe a carta e engoliu-a. Existe, por conseguinte, uma atividade de escrita por parte de algumas das suas moradoras que não deve ser negligenciada.

No recolhimento da Caridade, a escrita estava entregue à escrivã, a qual tinha acesso ao cartório, mas nunca o podia fazer sem a presença da ministra, por ser o local onde se

\footnotetext{
${ }^{23}$ Rosa Maria dos Serafins, também regente na primeira metade de setecentos, não sabia escrever.
} 
guardavam os livros e mais papéis, mas também o dinheiro e outros bens. Só as duas tinham as chaves do cartório. Competia-lhe escrever tudo o que dissesse respeito à vida da comunidade em livros adequados, sendo referidos nas constituições apenas os de despesa e receita. Como se tratava de um setor relevante, devia andar controlado, pelo que mensalmente a escrivã apresentava contas à ministra e às discretas.

A análise do recolhimento de S. Tiago da Misericórdia de Viana do Castelo, destinado a recolher meninas nobres, caídas em pobreza, tem uma realidade bem diferente. A atenção conferida à leitura e escrita das recolhidas está muito pouco presente nos seus estatutos de 1707, talvez por se subentender que já dominassem essas competências. Previa-se que as mulheres recebessem e escrevessem cartas, devendo umas e outras passar pela mão da regente antes de serem estregues aos destinatários, bem como a leitura dos estatutos todas as quartas-feiras, abstendo-se, no entanto, de indicar a leitora ${ }^{24}$.

Maior preocupação é expressa nas regras do recolhimento de Nossa Senhora da Esperança, administrado pela Santa Casa do Porto. Esta casa recebia meninas entre os 7 e os 25 anos, destinava-se a recolher órfãs, mas aceitava também porcionistas. No seu texto regulamentar de 1731 previa-se a expulsão da regente, caso permitisse que alguma recolhida mantivesse correspondência considerada ilícita com outra pessoa. Por ela passariam igualmente todas as cartas, menos as dirigidas ao provedor da Misericórdia e as que fossem expedidas da confraria e entregues pelo servo ou por um dos irmãos. Era fundamental controlar o que era escrito e o que era lido.

As meninas eram acompanhadas por uma mestra, que as devia ensinar em tudo "que pertence à creação de uma perfeita mulher" 25 . Nas refeições, uma das meninas lia e depois da merenda, ao meio da tarde, tinham uma "lição de ler e se lhes emenderão as matérias", ou seja, a mestra corrigia-as no que considerasse necessário ${ }^{26}$. $\mathrm{O}$ seu programa de formação incluía ainda ensino de doutrina e artes manuais. Também nesta casa se ouvia ler e se liam os estatutos duas vezes por mês, por uma das recolhidas. Era muito importante o conhecimento das regras para uma melhor adaptação às mesmas.

Nos recolhimentos analisados verifica-se uma maior preocupação de dotar as mulheres de competências no campo da leitura do que na escrita, o que sugere estar relacionado com a necessidade destas efetuarem leituras em certos momentos do dia. A escrita é menos considerada e está permanentemente sob vigilância da superiora. As leituras efetuadas eram igualmente controladas, pois só existiam livros permitidos dentro de portas, porém na

${ }^{24}$ Arquivo Distrital de Viana do Castelo, Fundo da Misericórdia, Livro dos estatutos do recolhimento de S. Tiago, 1707, não paginado.

25 FERREIRA, J. A. Pinto. Recolhimento de órfãs de Nossa Senhora da Esperança. (Fundado na cidade do Porto no séc. XVIII). Porto: Publicações da Câmara Municipal do Porto, s.d., p. 141.

${ }^{26}$ FERREIRA, J. A. Pinto. Recolhimento de órfãs de Nossa Senhora da Esperança ..., pp. 152-153. 
escrita, cada uma podia expressar sentimentos, vontades, intimidades que podiam causar escândalo e pôr em causa a integridade moral da casa.

\section{O recolhimento da Caridade e a sua "aula pública"}

O recolhimento da Caridade foi fundado pelo escultor bracarense António Pinto de Araújo, em 1768. No ano seguinte, o instituidor faleceu. Esta instituição tinha "numerus clausus", tal como os outros cinco recolhimentos da cidade (Santo António, Nossa Senhora da Penha de França, Santa Maria Madalena e São Gonçalo, Nossa Senhora do Rosário ou de São Domingos da Tamanca e Santa Teresa) ${ }^{27}$. Recebia 13 recolhidas, mais as educandas. Em 1794, a instituição contava com 41 mulheres. Tal como os restantes congéneres da cidade, também este recolhimento ultrapassou rapidamente o número limite, cedendo à procura. Estava localizado na rua do Lameiro e foi fundado numas casas que o benfeitor comprou para o efeito, onde foi instalado após autorização do arcebispo D. Gaspar de Bragança (1758-1789), sendo o último recolhimento da cidade a ser criado. Realça-se que o período da sua fundação está diretamente associado às suas funções. Este recolhimento foi o único de Braga onde funcionava uma escola para meninas, embora o arcebispo D. frei Caetano Brandão (1790-1805) interviesse neste campo de forma muito interessante, ao criar escolas na cidade e nos seus arredores em finais de setecentos, destinadas à aprendizagem de meninas pobres. Este prelado decidiu em 1792 fundar várias escolas para ensinar meninas a ler e escrever, mas também a fiar e a costurar. As aulas eram ministradas por uma mestra paga pela Mitra. ${ }^{28}$.

Ainda nesse ano erigiu o Conservatório do Menino Deus, destinado a acolher meninas órfãs e expostas, mas onde se recebiam também porcionistas. As internas aprendiam na instituição a leitura, a escrita, o cálculo, a doutrina e os bons costumes. Nas aulas eram também recebidas alunas externas ${ }^{29}$, à semelhança do que já existia no recolhimento da Caridade.

Mas em Braga passou a existir também a partir de 1785 o Colégio das Ursulinas, instituição iniciada pelo arcebispo D. José de Bragança (1741-1756), com o objetivo de acolher e educar raparigas e órfãs. Porém, a sua morte levou à interrupção do projeto. Foi com o seu sucessor, D. Gaspar de Bragança, que este avançou, com a ajuda da rainha D. Maria I. O colégio destinava-se às filhas dos estratos mais abastados em termos económicos, capazes de pagar 40 mil réis anuais. Aqui se procedia a uma aprendizagem religiosa, mas também se aprendia leitura, gramática, escrita, cálculo, geografia, história sagrada e de Portugal durante 4 horas

\footnotetext{
${ }^{27}$ ARAÚJO, Maria Marta Lobo de. Os recolhimentos femininos de Braga na Idade Moderna. IN: ABREU, Laurinda (ed.). Asistencia y Caridad como Estrategias de Intervención Social: Iglesia, Estado y Comunidad (s. XV-XX). Vitoria: Universidad del Pais Vasco, 2007, p. 301. Para além destes recolhimentos, houve pelo menos mais três projetos para erguer novas instituições congéneres que não vingaram.

${ }^{28}$ ABREU, José Paulo. Em Braga de 1790 a 1805. D. Frei Caetano Brandão: o reformador contestado. Braga: Universidade Católica Portuguesa; Faculdade de Teologia de Braga; Cabido Metropolitano de Braga, 1997, p. 178-179.

${ }^{29}$ ABREU, José Paulo. Em Braga de 1790 a 1805. D. Frei Caetano Brandão..., p. 179.
} 
diárias: duas de manhã e duas de tarde. Existia ainda uma hora diária para estudo e duas para os trabalhos manuais e aprendizagem de música ${ }^{30}$. O programa de estudos era abrangente e não se circunscrevia apenas aos rudimentos da escrita e da leitura. Ia muito para além disso.

Os novos projetos de ensino para mulheres criados em Braga em finais de setecentos são o resultado do investimento dos arcebispos, mas também de particulares e refletem um pouco o que se passa em várias regiões do país onde surgem escolas para o sexo feminino ${ }^{31}$.

O recolhimento da Caridade vivia sob a regra da Ordem Terceira da Santíssima Trindade, destinava-se a recolher raparigas e tinha dois objetivos claramente definidos nas suas constituições: o primeiro consistia na "reforma das suas vidas, aspirando a maior perfeição" e o segundo em "tratarem com todo o cuidado da boa educação das mininas, que hão de ser instruidas, não só na doutrina christã e bons custumes, mas tambem em todo o genero das prendas, e lavor do seu sexo"32. A instituição apresentava a novidade de lecionar aulas para meninas internas e externas, permitindo o acesso diário ao espaço interior de raparigas, fazendo-o, todavia, de forma muito controlada. Trata-se, por conseguinte, de um recolhimento com características diferentes dos já conhecidos, chamando a atenção para a multiplicidade de serviços disponibilizados às mulheres por estas casas, demonstrando a sua complexidade e, simultaneamente, a sua importância para a cultura escrita feminina.

O plano de estudos não é definido no regulamento e infelizmente esta instituição não possui arquivo conhecido, tornando-se impossível neste momento a análise do curriculum escolar das alunas ${ }^{33}$. Todavia, aprender doutrina, ler e escrever integravam o plano defendido por Verney para instruir as crianças do sexo feminino ${ }^{34}$.

Apesar disso, o ensino ministrado tem agora um novo sentido. Apesar de estarmos perante uma instituição de reclusão, ela abria-se diariamente para admitir na sua sala meninas externas. Tratava-se, por conseguinte, de uma escola onde alunas internas e externas aprendiam. Conferia-se uma maior utilidade ao ensino ministrado ao abrir-se a aula ao público, tal como a escola se denominava "aula publica". A instituição estava disponível para responder às necessidades da comunidade feminina, colocando os seus préstimos ao seu serviço $^{35}$.

Estas mudanças, são porém mais latas e vão exigir que não apenas as mulheres, mas todos tenham acesso à instrução para melhor responderem às exigências da sociedade ${ }^{36}$.

\footnotetext{
${ }^{30}$ SOUSA, Maria Paula Abreu P. E. dos. As Ursulinas e a educação da mulher: o colégio das Chagas em Braga (1785-1878). Cadernos do Noroeste, vol. 17, (1-2), p. 38-39, 53, 2002.

${ }^{31}$ LISBOA, João Luís; MIRANDA, Tiago C. P. dos Reis. A cultura escrita nos espaços privados. IN: MATTOSO, José (dir.). História da vida privada. A Idade Moderna. Lisboa: Círculo de Leitores, 2010, p. 357.

${ }^{32}$ Arquivo da Sé de Braga (doravante ASB), Livro dos estatutos do recolhimento da Caridade, 1768, não paginado.

${ }^{33} \mathrm{~A}$ nossa análise será realizada com base nos seus estatutos, que nesta instituição tomam a designação de constituições.

${ }^{34}$ VERNEY, Luis António. Verdadeiro Método de Estudar, vol. 5..., p. 127-135.

${ }^{35}$ MÓ ROMERO, Esperanza; RODRÍGUEZ GARCÍA, Margarita Eva. Educar? A quién y para qué?. IN: MORANT, Isabel (dir.). ORTEGA., M.; LAVRIN, A.; PERÉZ CANTÓ, P. (orgs.). Historia de las mujeres, II..., p. 731.

${ }^{36}$ IM HOF, Ulrich. A europa no século das Luzes. Lisboa: Ed. Presença, 1995, p. 188-196.
} 
Basta pensar, por exemplo, no Estado e nas competências dos homens que desempenhavam os mais altos cargos. Cada vez mais burocratizados, exigiam pessoas melhor preparadas a todos os níveis para responderam com eficácia às suas funções ${ }^{37}$.

No prólogo das Constituições dadas por D. Gaspar de Bragança ao recolhimento da Caridade no ano da sua fundação é claramente explicitado o que se pretende desta casa. $O$ arcebispo noticia a instrução das meninas internas, mas igualmente as "que de fora vierem a vossas aulas pera serem instruídas nos bons costumes e com todo o género de prendas e lavor próprio do seu sexo", o que segundo ele resultava em utilidade para a República ${ }^{38}$. O ensino era integrado na aprendizagem dos bons costumes, fazia parte da educação das meninas e era entendido como um bem de interesse público, uma vez que se revestia de utilidade.

As crianças eram educadas e instruídas por mestras de confiança, seguindo um modelo de vida que agradecia a Deus e conforme com o desejo do arcebispo: isto é, que conjugasse "perfeição da vida, mas também da utilidade pública" ${ }^{39}$. Seguindo os princípios do Iluminismo, o arcebispo menciona repetidamente no prólogo a marca da utilidade pública, convocando a mulher para um lugar na sociedade que não conhecia até então.

As 13 candidatas ao internamento sujeitavam-se a uma inquirição sobre a pureza de sangue, costumes, vida, saúde, mas também relativamente às competências apresentadas para serem mestras das meninas. Eram também obrigadas a pagar pelo menos 20 mil réis anualmente, quantia destinada à sua subsistência e não podiam ter mais de 45 anos de idade. Requeiram-se, por conseguinte, mulheres limpas de sangue, de boa vida e costumes, saudáveis e que não fossem velhas. Tinham um ano de noviciado e eram propostas a votos após terem três anos de hábito. Tratava-se, portanto, de uma instituição que tinha dentro de si várias categorias de mulheres: as que professavam, as educandas e as alunas externas. $O$ recolhimento era gerido por uma madre ministra, eleita por três anos e assessorada na governação por 4 deputadas e mais oficiais.

Como existia um ano de noviciado para as que seguiam a vida religiosa, havia no recolhimento uma mestra de noviças e um lugar destinado ao noviciado, separado dos aposentos das educandas.

As noviças estavam sujeitas a um programa distinto das educandas, mas também eram colocadas "algumas vezes a ler", pela sua mestra. Estavam dispensadas de trabalhos na instituição, embora nos dias santos fossem obrigadas a participar nos trabalhos da limpeza da cozinha, sendo vigiadas pela sua mestra, devendo este trabalho contribuir para formar mulheres humildes ${ }^{40}$. Estavam impedidas de falar com as educandas, mas podiam receber cartas ou recados, depois de escrutinados pela mestra. Estavam autorizadas a escrever para

\footnotetext{
${ }^{37}$ VOVELLE, Michel. Introdução. IN: VOVELLE, Michel (dir.). O homem do Iluminismo. Lisboa: Ed. Presença, 1997, p. 25-27.

${ }^{38}$ ASB, Livro dos estatutos do recolhimento da Caridade, 1768, não paginado.

${ }^{39} \mathrm{ASB}$, Livro dos estatutos do recolhimento da Caridade, 1768, não paginado.

${ }^{40}$ ASB, Livro dos estatutos do recolhimento da Caridade, 1768, não paginado.
} 
fora, mas apenas sob a vigilância da mestra, a qual via e lia as cartas antes de as expedir. O mesmo processo era seguido relativamente às missivas chegadas do exterior. Toda a correspondência era vistoriada, exceto a proveniente do confessor ou a que lhe era dirigida. Essas cartas tinham livre-trânsito, por se revestirem de um carácter meramente espiritual. As noviças deviam ler com frequência as constituições para conhecerem bem a vida para que se preparavam.

Mas se existia "numerus clausus" para as professas, também o havia para as educandas, pois não deviam ultrapassar o número de 33. As educandas eram meninas e jovens com idades compreendidas entre os 5 e os 20 anos de idade, período em que se modelava a sua personalidade, feita através de um processo de aprendizagem de normas e da escolarização. Tinham de pagar anualmente pelo menos 30 mil réis, mas admitia-se a possibilidade de aceitar meninas pobres e nobres gratuitamente, quando a instituição dispusesse de meios para o efeito. As educandas tinham ainda de se vestir e calçar por sua conta, ficando a casa obrigada somente a mandar lavar e cuidar da sua limpeza e a assisti-las na doença, exceto se os seus familiares as quisessem curar nas suas moradias ${ }^{41}$. Quando adoeciam, eram normalmente tratadas no espaço de clausura, porém em casos de contágio ou eram removidas para os hospitais ou para casa dos familiares, para evitar que a doença se propagasse a toda a comunidade. Essa era também a razão que levava a conhecer o seu estado de saúde no momento de ingresso, pois admitir meninas com doenças podia ser complicado em termos futuros, não somente pelas despesas adicionais, mas principalmente pelo perigo em que se colocava o recolhimento.

As constituições determinavam ainda a forma de trajar, obrigando as educandas a vestir da mesma maneira que as mestras, "porem o manto e veo serão da cor que se arbitrar, mas em todas uniforme os mais vestidos e calcado (sic) serão muito onestas" ${ }^{42}$. Apesar de este ser o prescrito, sabemos que em muitos espaços de clausura as normas não eram respeitadas e as recolhidas eram vaidosas no seu quotidiano, usando roupas e acessórios que não estavam autorizadas ${ }^{43}$.

\section{As mestras}

As professoras eram escolhidas pela ministra e discretas entre as que apresentasse melhores capacidades, ou sejam tivessem "milhor prestimo" e fossem mulheres virtuosas.

Após a eleição da ministra, esta elegia as discretas e conjuntamente com elas procedia à seleção das restantes oficiais. Era a altura de escolher também as mestras. Estava previsto que

${ }^{41}$ ARAÚJO, Maria Marta Lobo de. Higiene, doença e morte no recolhimento de Santa Maria Madalena de Braga (século XVIII). Revista Portuguesa de História, t. XLVII, p. 291-313, 2016.

${ }^{42}$ ASB, Livro dos estatutos do recolhimento da Caridade, 1768, não paginado.

${ }^{43}$ BRAGA, Isabel M. R. Mendes Drumond. Vaidades nos conventos femininos ou dificuldades em deixar a vida mundana (séculos XVII-XVIII). Revista de História, da Sociedade e da Cultura, 10, tomo I, p. 305-322, 2010. 
lecionassem de forma rotativa aos meses, quando possível, por forma a participarem no legado que para isso estava instituído. A ministra e as discretas (4 mulheres) podiam assistir às aulas, vigiando o que nelas se passava. A presença destas mulheres nas salas de aulas era entendida como uma supervisão, feita na forma de as "presidir", ou seja de as superentender. Competia-lhe averiguar se as aulas decorriam de forma ordeira e eram bem ministradas, devendo ter particular cuidado no referente à aula propriamente dita, isto é, ao ensino da leitura, da escrita e do cálculo, mas também da doutrina cristã e dos bons costumes. Por isso, pedia-se-lhes que visitassem as aulas frequentemente, não permitindo desleixo às mestras. Na observação deviam ter em consideração cada uma das disciplinas e a docente, ou seja, analisar o comportamento da mestra e as suas competências pedagógicas e científicas. Era altura de supervisionar para posteriormente advertir, quando necessário, mas nunca na presença das alunas. As mestras podiam ser repreendidas, mas fora do alcance das suas pupilas.

Competia também à ministra a receção das alunas externas e a sua distribuição pelas mestras. Quando a aluna apresentasse competências num campo, transitava para outra mestra para lhe serem ministradas outras competências. Cabia à ministra a tarefa de auditar as aprendizagens das alunas.

As mestras deviam ser peritas em todas as matérias que ensinavam às alunas, exigindose-lhes o cumprimento das suas obrigações ${ }^{44}$.

As eleitas não eram apenas consideradas professoras, eram também mães, amando-as em Cristo e demonstrando-lhes afeto e carinho. Deviam tratar as educandas com suavidade no ensino de leitura, escrita e cálculo, bem como ensiná-las a falar corretamente. Para as que tivessem intenção de ingressar em conventos, era-lhes ensinado Latim. Porém, todas aprendiam lavores.

Às professoras era exigido que preparassem bem o que ensinavam às alunas, principalmente no campo da leitura. Deviam ler previamente várias vezes os textos que dariam a ler às alunas, de forma a controlar aquilo que ensinavam e a ter em consideração as alunas externas, pois deviam combinar bem a preparação de umas e de outras. Por outro lado, impunha-se controlar o que se lia, num século em que a laicização ia avançando.

\section{O programa e a metodologia de ensino}

Apesar de estarmos perante mestras e alunas, as constituições reportam-se ainda a uma relação de mães e filhas, ao apelarem às educandas para não verem as mestras como superioras, devendo relacionar-se com elas como filhas, mas demonstrar-lhes a importância

\footnotetext{
${ }^{44}$ ASB, Livro dos estatutos do recolhimento da Caridade, 1768, não paginado.
} 
dos seus ensinamentos, quer espirituais, quer temporais. Este era pelo menos o ideal traçado nas suas constituições.

As mestras deveriam adotar o mesmo método para ensinar a doutrina cristã, não devendo ministrar às alunas "coisas muito altas que elas não entendão", ou seja assuntos complexos, fazendo acreditar na sua falta de entendimento. Deviam contentar-se em ensinar "simplesmente o que se contiver no compêndio de Doutrina christam pera a sua instrução", estendendo-se esta metodologia quer para as educandas, quer para as alunas externas. $\mathrm{O}$ método e os conteúdos deviam ser, portanto, simples, seguir o livro citado e abster-se de ensinar para além dele.

O número de alunas externas não era limitado, prevendo-se salas cheias de crianças e jovens. As alunas externas entravam por uma porta que diariamente se abria para o efeito, mas que se voltava a encerrar-se até elas saírem no final das aulas. Cabia às porteiras a gestão da porta, devendo manter em seu poder as chaves dessa e das restantes portas da instituição. Aqui, não existia apenas uma porteira como era normal nestas casas, mas sim duas, talvez por ter a "aula pública", o que provocava fluxo de entradas e saídas diárias. As porteiras eram consideradas mulheres de confiança, zelo e virtude. Vigiavam as portas, mas também as rodas, não devendo abrir umas e outras senão em caso de manifesta necessidade. Na instituição existiam duas rodas: uma na portaria e outra na sacristia. Eram também elas que abriam e fechavam as portas das salas onde decorriam as aulas. Exigia-se-lhes muita vigilância, quer nas portas, quer nas rodas, impedindo contactos com o exterior para além do autorizado pela ministra.

Tratando-se de uma instituição de reclusão, a abertura das portas era algo preocupante, que devia no caso em apreço ser ainda mais cuidada, porquanto diariamente se franqueava a porta para deixar entrar e sair as alunas externas.

Acreditamos que neste recolhimento houvesse mais do que uma sala, onde se incluiriam as alunas de várias idades e níveis de aprendizagem, o que exigia investimentos nas mestras, mas também nos equipamentos escolares ${ }^{45}$.

As normas são quase exclusivamente dirigidas para as meninas do internato. As externas seguiam-nas no que dizia respeito às aulas, sendo fornecidas poucas mais informações nas constituições.

Se a grande novidade deste recolhimento foi a criação da aula pública, as constituições dão particular relevo à educação tradicional das raparigas, referindo principalmente a sua formação moral. O programa educativo das educandas visava o aperfeiçoamento das suas virtudes, devendo estas ser preparadas para fazer "varias espiraçoens" a Deus quando de noite

${ }^{45}$ SONNET, Martine. Uma filha para educar. IN: DUBY, Georges; PERROT, Michelle (dir.). História das Mulheres. Do Renascimento à Idade Moderna. Porto: Ed. Afrontamento, 1994, p. 160. 
acordassem, como durante o dia deviam levantar-se com muita decência e modéstia e rezar à Santíssima Trindade, pedindo-lhe para não as deixar ofender. As mestras ensinavam as meninas a conservar, a sua pureza corporal e espiritual, de maneira a apresentarem-se dignamente à confissão e à comunhão; a respeitar as suas superioras e o próximo, a não mal dizer, a serem humildes, a frequentarem a missa, a serem devotas e a aplicarem-se na aprendizagem dos "bons livros" ${ }^{46}$. O programa assentava principalmente na conduta moral, contemplava atitudes para a noite e o dia e sublinhava aspetos morais e comportamentais de mulheres honestas ${ }^{47}$. A frequência dos sacramentos, a preservação das virtudes, a oração, o amor ao próximo, o respeito eram aspetos muito importantes que se refletiriam na aprendizagem, nas aulas, devendo esta ser feita através de manuais muito recomendados.

A componente moral era muito relevante e apelava a uma ligação ao sagrado, devendo as meninas repudiar o pecado moral e venial. As educandas eram ensinadas a preferir morrer do que ofender a Deus. Para tanto eram estimuladas a rezar e a ser muito devotas de Nossa Senhora, do Anjo da Guarda e das santas dos seus nomes ${ }^{48}$. A oração mental constituia também um caminho para o aperfeiçoamento moral, todavia, era aconselhada apenas às que fossem capazes de a praticar, uma vez que as mais pequenas não reuniam condições para o fazer ${ }^{49}$.

As educandas estavam ainda obrigadas a assistir à missa, a rezar o ofício divino, a ir ao coro diariamente para rezar um rosário, sendo nos domingos e dias santos cantado o segundo terço. Faziam ainda penitências, o que era vulgar em muitos recolhimentos.

As mestras deviam ainda ensinar as alunas as "leys da boa politica" colocando-as semanalmente a ler partes de livros sobre esta matéria. Estes livros eram lidos aos poucos, devendo a leitura ser sequencial, de forma que quando acabados, fossem novamente reiniciados. Com a existência de poucos compêndios, a repetição era uma maneira de economizar, mas também um método de ensino. Mas para além destes manuais, o que liam e consumiam estas meninas e jovens? Liam o que gostavam ou o que era possível ler? Possuíam livros pessoais? Perguntas a que de momento não conseguimos responder. A falta de outras fontes limita-nos a análise, embora o mesmo aconteça em muitas outras instituições congéneres, de que se desconhece a sua biblioteca e o seu arquivo.

As meninas eram ensinadas a ler em português e em latim e a escrever corretamente. Assim, faziam treslados de letra bem feita, ou seja, copiavam com letra desenhada, o modelo que era aconselhado e necessário seguir. Para além de ler e escrever, as alunas aprendiam

\footnotetext{
${ }^{46}$ ASB, Livro dos estatutos do recolhimento da Caridade, 1768, não paginado.

${ }^{47}$ MATOS, Artur Teodoro. Vivências, comportamentos e percursos das recolhidas de Santa Bárbara de Ponta Delgada nos séculos XVII a XX: contributos para uma monografia. IN: Colóquio Comemorativo dos 450 anos da cidade de Ponta Delgada- Actas. Ponta Delgada: Universidade dos Açores, 1999, p. 146.

${ }^{48}$ MARQUES, João Francisco. Oração e Devoções. IN: Azevedo, Carlos Moreira (dir.). História Religiosa de Portugal. vol. 2, Lisboa: Círculo de Leitores, 2000, p. 603-606.

49 TAVARES, Pedro Vilas Boas. Beatas, inquisidores e teólogos. Reacção portuguesa a Miguel de Molinos. t. 1, Porto: Faculdade de Letras da Universidade do Porto, 2002, p. 176-189, tese. de Doutoramento policopiada.
} 
também a falar bem, sendo corrigidas quando não pronunciavam corretamente as palavras. Era colocado particular enfase na leitura e na escrita, de maneira a preparar bem as pupilas nesta matéria.

Aprendiam ainda a cantar através das aulas de canto que lhes eram ministradas. Eram treinadas em cantochão e a tocar órgão, tendo idade para tanto. Ao mesmo tempo, aprendiam a bordar, fiar, fazer meia, cozer e rendilhar. Tinham ainda noções de limpeza, devendo ter os bens pessoais asseados.

Dotar as mulheres com várias competências era prepará-las para a vida depois de saírem do recolhimento. Conseguir um trabalho era uma forma de contribuírem para a economia doméstica ou sustentarem-se, nos casos em que viviam sozinhas ${ }^{50}$. A aprendizagem destas competências apetrechava-as ainda para serem boas donas de casa, esposas e mães.

Todas as sextas-feiras à noite, em capítulo, as educandas assumiam as suas faltas perante a mestra e as companheiras, ocasiões que as levariam ao arrependimento e à correção. Estes momentos coletivos de assunção de culpas objetivavam a publicitação dos erros e a sua emenda Não voltar a incorrer no erro era fundamental para o aperfeiçoamento moral ${ }^{51}$. Esses momentos eram também pedagógicos, pois deveriam contribuir para que os erros e faltas não fossem repetidas pelas companheiras.

\section{Considerações finais}

No século XVIII, a aprendizagem das mulheres alarga-se em termos culturais, muito à custa das novas propostas do Iluminismo. Nos conventos e recolhimentos, as mulheres já liam e escreviam, aprendendo em alguns deles estas competências. Porém, a abertura de aulas públicas criou um novo espaço para aprender, divulgando o ensino a um volume maior de mulheres.

Braga na segunda metade de setecentos conheceu um grande impulso na cultura escrita feminina, de que o recolhimento da Caridade é um exemplo. Aqui passou a funcionar uma "aula publica" com a preocupação de dotar as educandas internas e as alunas externas de várias competências, que contemplavam a leitura, a escrita, o latim, o canto e a correção da linguagem oral. Mas se esta era a novidade, a religião e a moral mantinham um lugar central da sua educação, demonstrando que apesar da mudança, continuava-se a privilegiar as virtudes morais e as competências religiosas na mulher.

\footnotetext{
${ }^{50}$ LIBERATO, Marco. Trento, a Mulher e o Controlo Social: o Recolhimento de S. Manços. IN: ABREU, Laurinda (ed.). Igreja, caridade e assistência na Península Ibérica (sécs. XVI-XVIII). Lisboa: Colibri/CIDHEUS, 2004, p. 287.

${ }^{51}$ FERNANDES, Maria de Lurdes Correia. Ignorância e confissão nas primeiras décadas do século XVII em Portugal. IN: Estudos de homenagem a João Francisco Marques. Porto: Faculdade de Letras da Universidade do Porto, 2001, p. 427-428.
} 


\section{Referências}

ABREU, José Paulo. Em Braga de 1790 a 1805. D. Frei Caetano Brandão: o reformador contestado. Braga: Universidade Católica Portuguesa; Faculdade de Teologia de Braga; Cabido Metropolitano de Braga, 1997.

ALGRANTI, Leila Mezan. Livros de devoção, atos de censura. Ensaios de História do livro e da leitura na américa Portuguesa (1750-1821). São Paulo: Editora Hucitec, 2004.

ALMEIDA, Teresa Sousa de. Correspondências. Usos da carta no século XVIII. IN: MONTEIRO, Nuno Gonçalo; ALMEIDA, Teresa Sousa de; ANASTÁCIO, Vanda (org.). Correspondências. Usos da carta no século XVIII. Lisboa: Edições Colibri/Fundação das Casas de Fronteira e Alorna, 2005.

ARAÚJO, Maria Marta Lobo de. Os recolhimentos femininos de Braga na Idade Moderna. IN: ABREU, Laurinda (ed.). Asistencia y Caridad como Estrategias de Intervención Social: Iglesia, Estado y Comunidad (s. XV-XX). Vitoria: Universidad del pais Vasco, 2007, p. 293-314.

ARAÚJO, Maria Marta Lobo de. Higiene, doença e morte no recolhimento de Santa Maria Madalena de Braga (século XVIII). Revista Portuguesa de História, t. XLVII, Coimbra, p. 291-313, 2016.

BELO, Maria Filomena Valente. Os recolhimentos femininos e a expansão (séculos XVI-XVII). IN: O rosto feminino da expansão portuguesa. Actas do congresso internacional, vol. I, Lisboa: s.e., 1994, p. 675-685.

BOLUFER, M.. Historia de las mujeres en la época moderna: selección de la bibliografia reciente. Cuadernos de Historia Moderna, p. 127-224, 1997.

BRAGA, Isabel M. R. Mendes Drumond. Cultura, Religião e Quotidiano. Lisboa: Hugin, 2005.

BRAGA, Isabel M. R. Mendes Drumond. Vaidades nos conventos femininos ou dificuldades em deixar a vida mundana (séculos XVII-XVIII). Revista de História, da Sociedade e da Cultura, 10, tomo I, Coimbra, p. 305-322, 2010.

CHARTIER, Roger. As práticas da escrita. IN: ARIÈS, Philippe; DUBY, Georges (dir.). História da vida privada. Do Renascimento ao Século das Luzes. Porto: Ed. Afrontamento, 1990, p. 113-160.

CHARTIER, Roger; JULIA, Dominique; CAMPÈRE Marie Madeleine. L'éducation en France du XVIe ao XVIIIe siècles. Paris: SEDES, 1976.

CAPEL, R. M.. La mujer española en el siglo XVIII: estado de la cuestión. In: Coloquio Internacional "Carlos III y su siglo". II. Madrid: s.e, p. 511-527. 
CASTRO, Maria de Fátima. O Recolhimento das Beatas de Santo António do Campo da Vinha. Bracara Augusta, vol. XLVI, Braga: Câmara Municipal de Braga, p. 169-249, 1995-1996.

FERNANDES, Maria de Lurdes Correia. Ignorância e confissão nas primeiras décadas do século XVII em Portugal. IN: Estudos de homenagem a João Francisco Marques. Porto: Faculdade de Letras da Universidade do Porto, 2001, p. 425-436.

FERREIRA, J. A. Pinto. Recolhimento de órfãs de Nossa Senhora da Esperança. (Fundado na cidade do Porto no séc. XVIII). Porto: Publicações da Câmara Municipal do Porto, s.d.

GANDELMAN, Luciana Mendes. Mulheres para um império: órfãs e caridade nos recolhimentos femininos da Santa Casa da Misericórdia (Salvador, Rio de Janeiro e Porto-século XVIII). Campinas: UNICAMP, 2005, tese de Doutoramento policopiada.

GARCÍA, Serrana. Una mirada a la evolución historiográfica de la historia de las mujeres. Semata. Ciencias sociais e humanidades, 20, p. 155-188, 2008.

IM HOF, Ulrich. A europa no século das Luzes. Lisboa: Ed. Presença, 1995.

LIBERATO, Marco. Trento, a Mulher e o Controlo Social: o Recolhimento de S. Manços. IN: ABREU, Laurinda (ed.). Igreja, caridade e assistência na Península Ibérica (sécs. XVI-XVIII). Lisboa: Colibri/CIDHEUS, 2004, p. 275-289.

LISBOA, João Luís; MIRANDA, Tiago C. P. dos Reis. A cultura escrita nos espaços privados. IN: Mattoso, José (dir.), História da vida privada. A Idade Moderna. Lisboa: Círculo de Leitores, 2010, p. 334-393.

LOPES, Maria Antónia. Mulheres, espaço e sociabilidade. A transformação dos papéis femininos em Portugal à luz de fontes literárias (segunda metade do século XVIII). Lisboa: Livros Horizonte, 1989.

LOPES, Maria Antónia. Proteç̧ão Social em Portugal. Coimbra: Imprensa da Universidade, 2010.

LÓPEZ-CORDÓN, María Vitória. La fortuna de escribir. Escritoras de los siglos XVII e XVIII. IN: MORANT, Isabel (dir.). ORTEGA., M.; LAVRIN, A.; PERÉZ CANTÓ, P. (orgs.). Historia de las mujeres en España y América Latina, II. Madrid: Cátedra, 2005, p. 199-200.

LÓPEZ-CORDÓN, María Vitória. Los estúdios históricos sobre las mujeres en la Edad Moderna: estado de la cuestión. Revista de Historiografia, 22, p. 147-181, 2015.

LÓPEZ, Roberto J.. De la cultura material a la cultura letrada. IN: DUBERT, Isidro (coord.). Historia de la Galicia Moderna. Santiago de Compostela: Universidade de Santiago de Compostela, 2012, p. 359-405. 
MACHADO, Carla Manuela Sousa. Entre a clausura e o século: $o$ recolhimento de Santo António do Campo da Vinha sob a administração da Misericórdia de Braga (séculos XVII-XVIII). Braga: Universidade do Minho, 2014, dis. de Mestrado policopiada.

MAGALHÃES, Justino. Ler e escrever no mundo rural do Antigo Regime. Braga: Universidade do Minho, 1993.

MARQUES, João Francisco. Oração e Devoções. IN: AZEVEDO, Carlos Moreira (dir.). História Religiosa de Portugal, vol. 2. Lisboa: Círculo de Leitores, 2000, p. 603-670.

MATOS, Artur Teodoro. Vivências, comportamentos e percursos das recolhidas de Santa Bárbara de Ponta Delgada nos séculos XVII a XX: contributos para uma monografia. In: Colóquio Comemorativo dos 450 anos da cidade de Ponta Delgada-Actas. Ponta Delgada: Universidade dos Açores, 1999, p. 141-152.

MÓ ROMERO, Esperanza; RODRÍGUEZ GARCÍA, Margarita Eva. Educar? A quién y para qué?. IN: MORANT, Isabel (dir.), ORTEGA., M.; LAVRIN, A.; PERÉZ CANTÓ, P. (orgs.),. Historia de las mujeres en España y América Latina, II. Madrid: Cátedra, 2005, pp. 729-756.

MONTESERRAT CARBONELL i Esteller, Sobreviuver a Barcelona. Dones, pobresa i assistência al segle XVIII. Barcelona: Euno Editorial, 1997.

MORUJÃO, Isabel. Bibliografia Monástica Feminina. Lisboa: Centro de Estudos de História Religiosa, 1995.

MORUJÃO, Isabel. Poesia e santidade: alguns contributos para uma percepção do conceito de santidade, a partir de duas biografias devotas de religiosas do século XVIII português. Via Spiritus, $\mathrm{n}^{\circ}$ 3, p. 235-261, 1996.

MORUJÃO, Isabel; SANTOS Zulmira. Literatura cultura popular em Portugal e no Brasilhomenagem a Arnaldo Saraiva. Porto: CITCEM, Afrontamento, 2011.

MORUJÃO, Isabel. Por trás da grade. Poesia conventual feminina em Portugal. Lisboa: Imprensa Nacional Casa da Moeda, 2013.

MORUJÃO, Isabel. Una escritura feminina diferente: los manuscritos culinários conventuales portugueses de la Edad Moderna. IN: Letras en la Celda. Cultura escrita de los conventos femininos de la España Moderna. Madrid: Iberoamericana-Vervnert, 2014, p. 439-455.

MORUJÃO, Isabel. Uma tipologia de quase silêncio. Um sermão de clarissa: texto e contexto. In: Vozes da Vida Religiosa Feminina. Experiências, Textualidades e Silêncios (Séculos XV-XXI). Lisboa: Centro de Estudos de História Religiosa/ Universidade Católica Portuguesa, 2015. 
REY CASTELAO, Ofelia. "La historia de las mujeres en Galicia. Un estado se la cuestión (19882008). Minius, 17, p. 191-234, 2009.

SILVA, Francisco Ribeiro da. O ensino público em Portugal no século XVII". IN: Primeiro encontro de História da Educação em Portugal. Lisboa: Fundação Calouste Gulbenkian, 1988, p. 115-124.

SILVA, Ricardo. Casar com Deus: vivências religiosas e espirituais femininas na Braga Moderna. Braga: Universidade do Minho, 2011, tese de Doutoramento policopiada.

SIXTO BARCIA, Ana Maria. Mujeres y cultura letrada en la Galicia Moderna. Santiago de Compostela: Facultade de Xeografía e Historia; Universidade de Santiago de Compostela, 2015, Tese de Doutoramento policopiada.

SONNET, Martine. Uma filha para educar. IN: DUBY, Georges; PERROT, Michelle (dir.). História das Mulheres. Do Renascimento à Idade Moderna. Porto: Ed. Afrontamento, 1994, p. 141179.

SOUSA Maria Paula Abreu P. E. dos. As Ursulinas e a educação da mulher: o colégio das Chagas em Braga (1785-1878). Cadernos do Noroeste, vol. 17, (1-2), p. 35-79, 2002.

TAVARES, Pedro Vilas Boas. Beatas, inquisidores e teólogos. Reacção portuguesa a Miguel de Molinos. t. 1, Porto: Faculdade de Letras da Universidade do Porto, 2002, p. 176-189, tese. de Doutoramento policopiada.

VERNEY, Luis António. Verdadeiro Método de Estudar. vol. 5, Lisboa: Sá da Costa, 1953.

VOVELLE, Michel. Introdução. IN: VOVELLE, Michel (dir.). O homem do Iluminismo. Lisboa. Ed. Presença, 1997, p. 7-28.

Recebido em: 14-06-2017 Aceito em: 11-07-2017 